Humanis Vol. 12 No. 1

\title{
PENINGKATAN HASIL BELAJAR MATERI OTONOMI DAERAH DALAM PELAJARAN PPKn METODE RESITASI
}

\author{
Sumarwoto \\ SMP Negeri 1 Pule Trenggalek \\ Email: langitpitu.harry@gmail.com
}

\begin{abstract}
Learning PPKn in class IX-B SMP Negeri 1 Pule Trenggalek has serious problems. In daily tests on regional autonomy, the average score is very low, namely 56.6. Students who have achieved mastery learning are 17 students or 51.5\%. There are 16 students who have not reached the completeness of learning or $48.5 \%$. The most mistakes made by students when describing the principles of regional autonomy, describing central government affairs, describing regional government affairs, examining regional autonomy implementers, describing the duties and powers of regional heads, describing the duties, functions and powers of DPRD, describing the importance of community participation in formulating public policies as well as looking for a relationship between the implementation of regional autonomy and the development carried out in their respective regions. Based on the results of discussions with colleagues, it was revealed that the learning that had been taking place did not involve the students maximally. In the teaching and learning process of PPKn, teachers do not provide much time for students to be involved in learning and discovery of learning concepts. Based on the above, it is necessary to conduct an action research by applying recitation. In this study, researchers used a classroom action research model. Observation / observation is divided into two learning cycles, each cycle carried out 2 meetings. Two cycles were made to improve the learning system being implemented. Based on the description of the discussion above, it is concluded that the application of the recitation method to regional autonomy in PPKn lessons begins by giving students assignments to make summaries of the articles contained in the clippings. In the next lesson each group gets an assignment to conduct a discussion. This is intended to increase student involvement in learning. The application of the recitation method can improve student learning outcomes on regional autonomy material in PPKn lessons.
\end{abstract}

Keywords: Learning Outcomes, Regional Autonomy, Recitation

\begin{abstract}
Abstrak: Pembelajaran PPKn di kelas IX-B SMP Negeri 1 Pule Trenggalek, mengalami permasalahan yang serius. Pada ulangan harian tentang otonomi daerah, didapat nilai rata-rata yang sangat rendah, yaitu 56,6. Siswa yang telah mencapai ketuntasan belajar sebanyak 17 siswa atau sebesar 51,5\%. Siswa yang belum mencapai ketuntasan belajar sebanyak 16 siswa atau sebesar 48,5\%. Kesalahan yang paling banyak dilakukan siswa saat menguraikan asas otonomi daerah, menguraikan urusan pemerintah pusat, menguraikan urusan pemerintah daerah, menelaah pelaksana otonomi daerah, menguraikan tugas dan wewenang kepala daerah, menguraikan tugas, fungsi dan wewenang DPRD, menguraikan pentingnya partisipasi masyarakat dalam merumuskan kebijakan publik serta mencari hubungan antara pelaksanaan otonomi daerah dengan pembangunan yang dilakukan di daerahnya masing-masing. Berdasar hasil diskusi dengan teman sejawat, terungkap bahwa pembelajaran yang selama ini berlangsung kurang melibatkan siswa secara maksimal. Dalam proses belajar mengajar PPKn, guru kurang memberikan banyak waktu kepada siswa untuk terlibat dalam pembelajaran dan penemuan konsep pembelajaran. Berdasar hal diatas maka perlu diadakan suatu penelitian tindakan dengan menerapkan resitasi. Pada penelitian ini, peneliti menggunakan model penelitian tindakan kelas. Pengamatan/observasi terbagi menjadi dua siklus pembelajaran, masing-masing siklus dilaksanakan 2 pertemuan. Dibuat dua siklus dimaksudkan untuk memperbaiki sistem pembelajaran yang dilaksanakan. Berdasarkan uraian pembahasan di atas, maka diperoleh simpulan bahwa penerapan metode resitasi pada materi otonomi daerah dalam pelajaran PPKn dimulai dengan memberikan tugas kepada siswa untuk membuat ringkasan dari artikel-artikel yang terdapat pada kliping. Pada pembelajaran selanjutnya setiap kelompok mendapatkan tugas untuk melakukan diskusi. Hal ini dimaksudkan untuk meningkatkan keterlibatan siswa dalam pembelajaran. Penerapan metode resitasi dapat meningkatkan hasil belajar siswa pada materi otonomi daerah dalam pelajaran PPKn.
\end{abstract}

Kata Kunci : Hasil Belajar, Otonomi Daerah, Resitasi 
PENDAHULUAN

Upaya peningkatan kualitas pembelajaran PPKn, membutuhkan keberanian untuk merombak cara atau pendekatan mengajar yang tidak memberikan peluang kepada siswa aktif dalam kegiatan pembelajaran (Suhito,2001:1). Salah satu cara untuk meningkatkan prestasi belajar PPKn adalah menggunakan metode pembelajaran yang variatif dan berpusat pada keterlibatan siswa.

Didalam interaksi belajar mengajar, guru memegang kendali utama untuk tercapainya tujuan pembelajaran. Guru harus memiliki ketrampilan mengajar, mengelola tahapan pembelajaran, memanfaatkan metode pembelajaran, memilih dan menetapkan metode pembelajaran, menggunakan media dan mengalokasikan waktu. Keenam hal itu merupakan pendekatan guru untuk mengkomunikasikan tindakan mengajarnya, demi tercapainya tujuan pembelajaran. Metode pembelajaran berperan dalam menentukan kondisi pembelajaran yang kondusif dan menyenangkan. Guru yang mengajar dengan melibatkan emosional serta mental siswa, serta menempatkan siswa sebagai subjek pembelajaran, maka akan mendapatkan siswa itu terlibat aktif dalam pembelajaran itu sendiri. Siswa akan dengan mudah dapat memahami apa yang disampaikan guru, karena siswa sendiri yang mengamati, menganalisis, menyimpulkan bahkan yang menemukan sendiri konsep pembelajaran.

Belajar PPKn hanya bisa dilakukan dengan menggunakan konsep yang telah dicapai sebelumnya. Dalam PPKn terdapat konsep prasyarat sebagai dasar untuk memahami konsep selanjutnya. Dengan demikian dalam mempelajari PPKn, konsep sebelumnya harus benar-benar dikuasai agar dapat memahami konsep-konsep selanjutnya. Kecenderungan sikap guru yang memberikan pembelajaran PPKn dengan ceramah, mengajak siswa untuk membaca bahan ajar serta menghafal materi mengakibatkan siswa cenderung merasa bosan, jengkel, dan tidak adanya kemauan dalam benak siswa untuk mendalaminya. Pembelajaran PPKn di kelas IX-B SMP Negeri 1 Pule Trenggalek, mengalami permasalahan yang serius. Pada ulangan harian tentang otonomi daerah, didapat nilai rata-rata yang sangat rendah, yaitu 56,6. Siswa yang telah mencapai ketuntasan belajar sebanyak 17 siswa atau sebesar $51,5 \%$. Sedangkan siswa yang belum mencapai ketuntasan belajar sebanyak 16 siswa atau sebesar $48,5 \%$.

Kesalahan yang paling banyak dilakukan siswa saat menguraikan asas otonomi daerah, menguraikan urusan pemerintah pusat, menguraikan urusan pemerintah daerah, menelaah pelaksana otonomi daerah, menguraikan tugas dan wewenang kepala daerah, menguraikan tugas, fungsi dan wewenang DPRD, menguraikan pentingnya partisipasi masyarakat dalam merumuskan kebijakan publik serta mencari hubungan antara pelaksanaan otonomi daerah dengan pembangunan yang dilakukan di daerahnya masing-masing. Dari observasi perangkat pembelajaran dan diskusi yang dilaksanakan bersama teman sejawat didapat data bahwa pembelajaran PPKn selama ini berlangsung hanya dengan menggunakan metode ceramah tanpa 
disertai dengan metode lain yang dapat melibatkan siswa dalam pembelajaran. Siswa hanya mendengar dan mengerjakan tugas dari guru, tanpa adanya kesempatan untuk mengolah materi pembelajaran melalui proses penemuan konsep. Guru juga tidak menggunakan media pembelajaran yang dapat mengkonkritkan materi. Dalam mengajarkan materi PPKn tentang otonomi daerah, kegiatan dimulai dengan memberi tugas kepada siswa untuk mendemonstrasikan kembali keterangan yang telah diberikan oleh guru. Siswa mencatat keterangan guru disertai tugas menyelesaikan materi yang telah diterangkan. Kegiatan diakhiri dengan menjawab soal yang terdapat dibagian akhir materi.

Permasalahan pembelajaran PPKn ini, hendaknya segera dicari solusinya agar mencapai keberhasilan dalam belajar. Suatu tanda seorang telah melakukan kegiatan belajar adalah apabila terjadi perubahan perilaku pada diri seorang tersebut. Indikator keberhasilan suatu pembelajaran dilihat sejauh mana perubahan perilaku pada diri siswa terjadi. Makin tinggi derajat perubahan yang dialami siswa setelah melakukan pembelajaran, maka makin tinggi pula keberhasilan pembelajaran tercapai. Jelasnya, jika terjadi perubahan pada diri siswa setelah mengalami pembelajaran, maka pembelajaran itu dikatakan berhasil. Demikian pula sebaliknya, jika tidak terjadi perubahan perilaku setelah siswa mengalami pembelajaran, maka dikatakan proses pembelajaran itu tidak berhasil.

Guru dalam mengajar hendaknya memperhatikan tingkat perkembangan mental siswa. Setiap siswa memiliki tingkat perkembangan yang berbeda.
Setiap siswa memiliki karakteristik pribadi dan sosial yang unik. Pengajaran perlu disesuaikan dengan karakteristik pribadi dan sosial dari siswa terdiri atas ciri-ciri psikis, ciri-ciri fisik dan ciri-ciri fungsional.

PPKn hendaknya disampaikan dengan orientasi pembelajaran yang bermakna, yaitu pembelajaran yang mengutamakan pengertian atau pemahaman konsep dan penerapannya dalam kehidupan. Agar suatu kegiatan belajar mengajar menjadi suatu pembelajaran yang bermakna maka kegiatan belajar mengajar harus bertumpu pada pembelajaran kontekstual. Menurut Chickering dan Gamson (Bonwell dan Eison, 1991:1) dalam belajar siswa harus melakukan sesuatu yang lebih dari sekedar mendengarkan, untuk bisa terlibat aktif para siswa itu harus terlibat dalam tugas yang perlu pemikiran tingkat tinggi seperti tugas analisis, sintesis, dan evaluasi.

Metode pembelajaran yang diterapkan oleh guru dalam pembelajaran, diharapkan mampu meningkatkan pemahaman siswa akan konsep pembelajaran yang diberikan, sehingga terbentuklah pengetahuan jangka panjang. Menguatnya pemahaman akan konsep pelajaran yang berupa pengetahuan jangka panjang sebagai indikasi terjadinya perubahan perilaku siswa. Perubahan perilaku sebagai tanda bahwa pembelajaran yang dilakukan oleh guru telah berhasil.

Berdasar hal diatas maka perlu diadakan suatu penelitian tindakan dengan menerapkan suatu metode yang dapat membimbing siswa dalam proses penemuan, sehingga keterlibatan siswa 
dalam proses pembelajaran tinggi. Peneliti akan menerapkan metode pembelajaran resitasi. Dalam metode resitasi, siswa dituntut untuk mengulang materi pembelajaran sehingga mencapai tingkat kesempurnaan, dibimbing untuk belajar mandiri, diberi tugas untuk mendapatkan pengetahuan awal yang akan dipergunakan untuk membentuk pengetahuan yang akan dipelajari.

\section{Hipotesis}

Dengan menerapkan metode resitasi, maka hasil belajar siswa kelas IXB SMP Negeri 1 Pule Trenggalek pada materi otonomi daerah dalam pelajaran PPKn, akan meningkat.

\section{METODE PENELITIAN}

Pada penelitian ini, peneliti menggunakan model penelitian tindakan kelas. Pengamatan/observasi terbagi menjadi dua siklus pembelajaran, masingmasing siklus dilaksanakan 2 pertemuan. Pada masing-masing siklus pembelajaran dikenai perlakuan yang sejenis dengan bobot yang beda. Dibuat dua siklus dimaksudkan untuk memperbaiki sistem pembelajaran yang dilaksanakan.

Observasi dilakukan oleh peneliti dan teman sejawat, bersamaan dengan pelaksanaan tindakan pembelajaran. Observasi dilakukan pada tiga aspek. Aspek pertama yang diobservasi adalah kesesuaian tindakan pembelajaran dengan rencana pembelajaran yang telah disusun.. Apakah tindakan pembelajaran yang dilakukan oleh peneliti telah sesuai dengan rencana pembelajaran yang telah disusun apa tidak. Aspek yang kedua adalah interaksi antara guru dengan siswa. Dalam tindakan pembelajaran yang berlangsung, sejauh mana siswa terlibat aktif dalam pembelajaran yang dilakukan oleh guru. Aspek yang ketiga adalah keefektifan penerapan metode pembelajaran terhadap peningkatan prestasi belajar. Selanjutnya peneliti mengadakan analisis data untuk mengetahui kendala-kendala dan perubahan yang terjadi selama tindakan pembelajaran dilakukan. Pada tahap refleksi ditetapkan apakah perlu dilaksanakan siklus selanjutnya apa tidak. Jika perlu, maka disusun perencanaan siklus selanjutnya.

\section{HASIL DAN PEMBAHASAN}

Pengolahan data yang diperlukan dimulai dengan menentukan hasil post test yang dilakukan dalam setiap siklus, adalah dengan melakukan penjumlahan nilai yang diperoleh siswa, yang selanjutnya dibagi dengan jumlah siswa yang ada di kelas tersebut sehingga diperoleh rata-rata hasil post test. Pembahasan hasil penelitian, diuraikan sebagai berikut:

\section{Kondisi Awal}

Data hasil ulangan materi otonomi daerah dalam pelajaran PPKn sebagai berikut:

\section{Tabel 1.}

Hasil Ulangan Harian/Pra Tindakan

\begin{tabular}{|c|l|l|}
\hline No & \multicolumn{1}{|c|}{ Deskripsi Hasil } & Ket \\
\hline 1 & Jumlah Nilai & 1870 \\
\hline 2 & Rata-rata Nilai & 56,6 \\
\hline 3 & Jumlah Siswa yang Tuntas & 17 \\
\hline 4 & Persentase ketuntasan & $\begin{array}{l}51,5 \\
\%\end{array}$ \\
& & \\
\hline
\end{tabular}

Berdasarkan data di atas diperoleh simpulan bahwa nilai rata-rata sebesar 56,6 . Siswa yang telah mencapai 
ketuntasan belajar sebanyak 17 siswa atau sebesar 51,5\%. Sedangkan siswa yang belum mencapai ketuntasan belajar sebanyak 16 siswa atau sebesar 48,5\%. Dari data ini dapat disimpulkan bahwa ketuntasan belajar siswa secara klasikal belum tercapai, karena ketuntasan belajar secara klasikal yang diharapkan sebesar $85 \%$.

2. Data Penyusunan Rencana Pelaksanaan Pembelajaran

Hasil supervisi perangkat pembelajaran pada pertemuan pertama, pertemuan kedua pada masing-masing siklus sebagai berikut:

Tabel 2.

Rekap Data Supervisi Penyusunan RPP

\begin{tabular}{|c|c|c|c|c|c|}
\hline \multirow{3}{*}{ No } & \multirow{3}{*}{$\begin{array}{c}\text { Aspek yang } \\
\text { Dinilai }\end{array}$} & \multirow{2}{*}{\multicolumn{2}{|c|}{$\begin{array}{c}\text { Siklus I } \\
\begin{array}{c}\text { Pertemuan } \\
\text { Ke }\end{array}\end{array}$}} & \multirow{2}{*}{\multicolumn{2}{|c|}{$\begin{array}{c}\text { Siklus II } \\
\text { Pertemuan } \\
\text { Ke }\end{array}$}} \\
\hline & & & & & \\
\hline & & I & II & I & II \\
\hline 1 & $\begin{array}{l}\text { Perumusan } \\
\text { tujuan } \\
\text { pembelajaran }\end{array}$ & 3 & 3 & 4 & 4 \\
\hline 2 & $\begin{array}{l}\text { Perumusan } \\
\text { dan } \\
\text { pengorganisas } \\
\text { ian materi } \\
\text { ajar }\end{array}$ & 2 & 3 & 4 & 4 \\
\hline 3 & $\begin{array}{l}\text { Penetapan } \\
\text { sumber/media } \\
\text { pembelajaran }\end{array}$ & 3 & 3 & 3 & 4 \\
\hline 4 & $\begin{array}{l}\text { Penilaian } \\
\text { kegiatan } \\
\text { pembelajaran }\end{array}$ & 3 & 4 & 3 & 3 \\
\hline 5 & $\begin{array}{l}\text { Penilaian } \\
\text { proses } \\
\text { pembelajaran }\end{array}$ & 3 & 4 & 4 & 3 \\
\hline 6 & $\begin{array}{l}\text { Penilaian } \\
\text { hasil belajar }\end{array}$ & 2 & 3 & 3 & 4 \\
\hline \multicolumn{2}{|c|}{ Jumlah } & 16 & 20 & 21 & 22 \\
\hline \multicolumn{2}{|c|}{ Rata-rata } & 2,66 & 3,33 & 3,5 & 3,67 \\
\hline \multicolumn{2}{|c|}{$\begin{array}{l}\text { Rata-rata } \\
\text { Seluruhnya }\end{array}$} & \multicolumn{2}{|c|}{2,99} & \multicolumn{2}{|c|}{3,58} \\
\hline
\end{tabular}

Kriteria Penskoran RPP

\begin{tabular}{|c|l|}
\hline Jumlah Skor & Keterangan \\
\hline 5 & Sangat Baik \\
\hline 4 & Baik \\
\hline 3 & Cukup \\
\hline 2 & Kurang \\
\hline 1 & Sangat Kurang \\
\hline
\end{tabular}

Ketercapaian Penilaian RPP

\begin{tabular}{|c|c|c|l|}
\hline $\begin{array}{c}\text { Rentang } \\
\text { Nilai }\end{array}$ & Skor & Nilai & Keterangan \\
\hline $27-30$ & $3,50-4,00$ & A & Sangat Baik \\
\hline $21-26$ & $2,75-3,49$ & B & Baik \\
\hline $14-20$ & $2,00-2,74$ & C & Cukup \\
\hline $0-13$ & $\leq 2,00$ & D & Kurang \\
\hline
\end{tabular}

Berdasar tabel: 1 dapat diketahui hasil dari perencanaan yang dibuat oleh peneliti pada siklus pertama yang dinilai oleh observer penyusunan RPP pertemuan pertama sebesar 2,66 dengan kategori cukup (C), dan pada pertemuan keduaa sebesar 3,33 dengan kategori baik (B). Sehingga rata-rata skor yang didapat dari pertemuan I dan pertemuan II adalah 2,99 dengan kategori baik (B). Dengan melihat dari pencapaian, guru mencapai target indikator keberhasilan 75,5\%. Dapat disimpulkan oleh peneliti bahwa adanya peningkatan dari setiap pertemuan.

Sedangkan hasil dari perencanaan yang dibuat oleh peneliti pada siklus kedua yang dinilai oleh observer penyusunan RPP pertemuan pertama sebesar 3,5 dengan kategori sangat baik (A), pertemuan kedua sebesar 3,67 dengan kategori sangat baik (A), sedangkan rata-rata skor yang didapat dari pertemuan pertama dan pertemuan kedua sebesar 3,58. Dengan melihat dari pencapaian, guru mencapai target indikator keberhasilan 93,25\%. Dapat 
Humanis Vol. 12 No. 1

disimpulkan oleh peneliti bahwa adanya peningkatan dari setiap pertemuan, sehingga dapat dikatakan bahwa pada siklus II ini rencana pelaksanaan pembelajaran dikatakan berhasil.

\section{Data Hasil Observasi Aktivitas Guru}

Hasil observasi kegiatan guru diuraikan dalam tabel dibawah ini:

Tabel 3.

Data Hasil Observasi Aktivitas Guru

\begin{tabular}{|c|c|c|c|c|c|}
\hline \multirow{3}{*}{$\begin{array}{l}\mathrm{N} \\
\mathrm{O}\end{array}$} & \multirow{3}{*}{$\begin{array}{c}\text { Aspek Yang } \\
\text { Dinilai }\end{array}$} & \multirow{2}{*}{\multicolumn{2}{|c|}{$\begin{array}{c}\text { SIKLUS I } \\
\begin{array}{c}\text { Pertemuan } \\
\mathrm{Ke}\end{array}\end{array}$}} & \multirow{2}{*}{\multicolumn{2}{|c|}{$\begin{array}{c}\text { SIKLUS I } \\
\text { Pertemuan } \\
\text { Ke }\end{array}$}} \\
\hline & & & & & \\
\hline & & $\mathrm{I}$ & II & I & II \\
\hline $\mathrm{A}$ & \multicolumn{5}{|c|}{ Kegiatan Pendahuluan } \\
\hline 1 & $\begin{array}{l}\text { Menyiapkan } \\
\text { fisik \& psikis } \\
\text { siswa }\end{array}$ & 3 & 3 & 4 & 4 \\
\hline 2 & $\begin{array}{l}\text { Mengaitkan } \\
\text { pembelajaran } \\
\text { dengan } \\
\text { pengalaman } \\
\text { siswa }\end{array}$ & 3 & 3 & 4 & 4 \\
\hline 3 & $\begin{array}{l}\text { Menyampaika } \\
\mathrm{n} \text { tujuan dan } \\
\text { rencana } \\
\text { kegiatan }\end{array}$ & 4 & 4 & 4 & 4 \\
\hline B & \multicolumn{5}{|l|}{ Kegiatan Inti } \\
\hline 1 & $\begin{array}{l}\text { Melakukan } \\
\text { appersepsi }\end{array}$ & 3 & 3 & 4 & 4 \\
\hline 2 & $\begin{array}{l}\text { Materi } \\
\text { pembelajaran } \\
\text { sesuai } \\
\text { indikator } \\
\text { materi }\end{array}$ & 3 & 4 & 3 & 4 \\
\hline 3 & $\begin{array}{l}\text { Menyampaika } \\
\mathrm{n} \text { strategi } \\
\text { pembelajaran } \\
\text { yang mendidik }\end{array}$ & 3 & 3 & 3 & 3 \\
\hline 4 & $\begin{array}{l}\text { Menerapkan } \\
\text { langkah- } \\
\text { langkah } \\
\text { pembelajaran }\end{array}$ & 3 & 4 & 4 & 4 \\
\hline 5 & $\begin{array}{l}\text { Memanfaatka } \\
\mathrm{n}\end{array}$ & 3 & 4 & 3 & 4 \\
\hline
\end{tabular}

\begin{tabular}{|c|c|c|c|c|c|}
\hline & $\begin{array}{l}\text { sumber/media } \\
\text { pembelajaran }\end{array}$ & & & & \\
\hline 6 & $\begin{array}{l}\text { Melibatkan } \\
\text { siswa dalam } \\
\text { pembelajaran }\end{array}$ & 3 & 3 & 4 & 3 \\
\hline 7 & $\begin{array}{l}\text { Menggunakan } \\
\text { bahasa yang } \\
\text { benar dan } \\
\text { tepat }\end{array}$ & 3 & 3 & 3 & 3 \\
\hline 8 & $\begin{array}{l}\text { Berprilaku } \\
\text { sopan dan } \\
\text { santun }\end{array}$ & 3 & 3 & 4 & 3 \\
\hline $\mathrm{C}$ & Kegiatan Penut & & & & \\
\hline 1 & $\begin{array}{l}\text { Membuat } \\
\text { simpulan } \\
\text { bersama siswa }\end{array}$ & 3 & 3 & 4 & 4 \\
\hline 2 & $\begin{array}{l}\text { Melakukan } \\
\text { evaluasi }\end{array}$ & 3 & 4 & 3 & 4 \\
\hline 3 & $\begin{array}{l}\text { Melakukan } \\
\text { refleksi }\end{array}$ & 3 & 3 & 4 & 4 \\
\hline 4 & $\begin{array}{l}\text { Memberikan } \\
\text { tugas sebagai } \\
\text { bentuk tindak } \\
\text { lanjut }\end{array}$ & 3 & 3 & 4 & 4 \\
\hline \multicolumn{2}{|c|}{ Jumlah } & 46 & 50 & 55 & 56 \\
\hline \multicolumn{2}{|c|}{ Rata-rata } & 3,06 & 3,33 & 3,73 & 3,66 \\
\hline \multicolumn{2}{|c|}{$\begin{array}{l}\text { Rata-rata } \\
\text { seluruhnya }\end{array}$} & \multicolumn{2}{|c|}{3,19} & \multicolumn{2}{|c|}{3,69} \\
\hline
\end{tabular}

Keterangan Ketercapaian Hasil Observasi

\begin{tabular}{|c|l|c|l|}
\hline $\begin{array}{l}\text { Rentang } \\
\text { Nilai }\end{array}$ & \multicolumn{1}{|c|}{ Skor } & Nilai & Keterangan \\
\hline $66-75$ & $3,50-4,00$ & A & Sangat Baik \\
\hline $52-65$ & $2,75-3,49$ & B & Baik \\
\hline $38-51$ & $2,00-2,74$ & C & Cukup \\
\hline $0-37$ & $\leq 2,00$ & D & Kurang \\
\hline
\end{tabular}

Berdasarkan table 3 dapat diketahui skor hasil dari pelaksanaan pembelajaran siklus pertama pada pertemuan pertama sebesar 3,06 dengan kategori baik (B), pertemuan kedua sebesar sebesar 3,33 dengan kategori baik (B). Sedangkan rata-rata skor hasil observasi pertemuan pertama dan kedua sebesar 3,19 dengan kategori baik (B). Hal ini dapat disimpulkan oleh peneliti 
bahwa adanya peningkatan dari setiap pertemuan pada siklus pertama

Sedangkan skor hasil dari pelaksanaan pembelajaran siklus kedua pertemuan pertama sebesar 3,69 dengan kategori sangat baik (A), dan skor pada pertemuan kedua sebesar 3,66 dengan kategori sangat baik (A). Sedangkan skor rata-rata pertemuan pertama dan kedua sebesar 3,69 dengan kategori sangat baik (A). Dapat disimpulkan oleh peneliti bahwa adanya peningkatan dari setiap pertemuan, sehingga dapat dikatakan bahwa pada siklus kedua ini rencana pelaksanaan pembelajaran dikatakan berhasil.

\section{Data Hasil Observasi Aktivitas Siswa \\ Kegiatan observasi ini dilakukan} bersamaan dengan kegiatan pelaksanaan tindakan. Kegiatan ini dilakukan peneliti dan teman sejawat. Hasil pengamatan aktivitas siswa ditunjukkan pada tabel dibawah ini:

Tabel 4.

Hasil Observasi Aktivitas Siswa

\begin{tabular}{|c|c|c|c|c|c|c|c|c|c|c|c|c|}
\hline \multirow{3}{*}{ Uraian } & \multicolumn{4}{|c|}{ SIKLUS I } & \multicolumn{4}{c|}{ SIKLUS II } \\
\cline { 2 - 14 } & \multicolumn{3}{|c|}{ Pertemuan I } & \multicolumn{2}{c|}{ Pertemuan II } & \multicolumn{3}{c|}{ Pertemuan I } & \multicolumn{2}{c|}{ Pertemuan II } \\
\cline { 2 - 14 } & A & B & C & A & B & C & A & B & C & A & B & C \\
\hline Jumlah & 75 & 86 & 104 & 77 & 83 & 101 & 99 & 92 & 112 & 104 & 104 & 118 \\
\hline Rata-rata & 2,27 & 2,6 & 3,15 & 2,33 & 2,51 & 3,06 & 3,0 & 2,78 & 3,39 & 3,15 & 3,15 & 3,57 \\
\hline
\end{tabular}

Keterangan:

$\mathrm{A}=$ Keaktifan Menyampaikan Pendapat

$\mathrm{B}=$ Keaktifan Menyelesaikan Tugas

$\mathrm{C}=$ Ketertiban

Ketercapaian Penilaian Observasi

\begin{tabular}{|c|c|l|}
\hline Skor & Nilai & Keterangan \\
\hline $3,10-4,00$ & A & Sangat Baik \\
\hline $2,1-3,00$ & B & Baik \\
\hline $1,01-2,00$ & C & Cukup \\
\hline$\leq 1,00$ & D & Kurang \\
\hline
\end{tabular}

Dari tabel 4, tampak bahwa ratarata skor untuk indikator keberanian bertanya/berpendapat pada pertemuan pertama siklus pertama sebesar 2,27. Mengalami kenaikan sebesar 0,6 pada pertemuan kedua. Pada siklus kedua pertemuan pertama, skor yang didapat sebesar 3,0 dan mengalami kenaikan 0,15 pada pertemuan kedua. Hanya ada beberapa siswa yang mampu mengajukan pertanyaan ketika beberapa kelompok mempresentasikan hasil kerja. Siswa malu-malu untuk menjawab. Kebanyakan siswa tidak berani mengajukan pertanyaan walaupun belum jelas. Kemandirian siswa untuk mengerjakan tugas masih kurang. Kerja kelompok berlangsung kurang maksimal, karena siswa yang kurang pandai hanya mengandalkan hasil kerja teman yang pandai. Kerja kelompok kurang efektif. Kegiatan masih banyak dimonopoli oleh siswa yang pandai. Sedangkan siswa yang kurang pandai, 
hanya mengandalkan hasil kerja temannya. Tugas yang dikerjakan secara berkelompok, kurang efektif karena kegiatan dimonopoli oleh siswa yang lebih pandai. Sebaiknya proses pembelajaran dilakukan secara mandiri oleh siswa, sehingga kegiatan tidak dimonopoli oleh siswa yang pandai.

Media pembelajaran berupa lingkungan sekolah, kurang efektif sehingga waktu yang dialokasikan dalam pembelajaran tidak terlaksana dengan baik. Sebaiknya proses pembelajaran dilakukan secara mandiri oleh siswa, sehingga kegiatan tidak dimonopoli oleh siswa yang pandai. Siswa mampu menyusun model PPKn melalui kegiatan mensketsa soal dengan bimbingan guru. Namun pelaksanaan kerja kelompok tidak berjalan baik, karena siswa yang kurang pandai mengandalkan hasil kerja teman yang pandai. Tidak semua siswa mempunyai kemauan untuk menyelesaikan soal.

Pada indikator ketertiban, siswa mendapat skor 3,15 pada siklus pertama pertemuan pertama. Pada pertemuan kedua mengalami penurunan sebesar 0,9. Pada pertemuan pertama di siklus kedua, skor yang didapat sebesar 3,39 dan mengalami kenaikan sebesar 0,18 pada pertemuan kedua. Sewaktu presentasi hasil kelompok dilakukan, banyak siswa yang tidak dapat melakukan dengan baik. Hal ini disebabkan karena siswa baru pertama mengalami hal yang demikian. Hal ini berakibat tidak maksimalnya siswa menyerap konsep yang diajarkan. Siswa dilibatkan secara langsung dalam pembelajaran dengan cara bersentuhan secara langsung dengan objek pembelajaran, melalui kegiatan diskusi dalam kelompok kecil. Siswa dilibatkan secara langsung dalam menyusun simpulan. Siswa mempresentasikan hasil diskusi di depan kelas.

\section{Data Hasil Post Test/Evaluasi \\ Hasil test/ evaluasi pada setiap siklus diuraikan sebagai berikut:}

Tabel 5.

Hasil Post Test/ Evaluasi

\begin{tabular}{|l|c|c|}
\hline \multicolumn{1}{|c|}{ Uraian } & Siklus I & Siklus II \\
\hline Jumlah Nilai & 2280 & 2615 \\
\hline Rata-rata Nilai & 69 & 79,2 \\
\hline $\begin{array}{l}\text { Jumlah Siswa yang } \\
\text { Tuntas }\end{array}$ & 22 & 29 \\
\hline $\begin{array}{l}\text { Persentase } \\
\text { ketuntasan }\end{array}$ & $66,7 \%$ & $87,9 \%$ \\
\hline
\end{tabular}

Dari tabel 5, didapat data bahwa nilai rata-rata hasil test/ evaluasi siklus pertama sebesar 69. Siswa yang telah mencapai ketuntasan belajar sebanyak 22 siswa atau sebesar $66,7 \%$. Sedangkan siswa yang belum mencapai ketuntasan belajar sebanyak 11 siswa atau sebesar $33,3 \%$. Dari data ini dapat disimpulkan bahwa disiklus pertama ketuntasan belajar siswa secara klasikal belum tercapai, karena ketuntasan belajar secara klasikal yang diharapkan sebesar 85\%. Maka diperlukan siklus lanjutan.

Nilai rata-rata hasil test/ evaluasi siklus kedua sebesar 79,2. Siswa yang telah mencapai ketuntasan belajar sebanyak 29 siswa atau sebesar $87,9 \%$. Sedangkan siswa yang belum mencapai ketuntasan belajar sebanyak 4 siswa atau sebesar $12,1 \%$. Maka dapat disimpulkan bahwa disiklus kedua ketuntasan belajar siswa secara klasikal telah tercapai, karena ketuntasan belajar secara klasikal yang diharapkan sebesar $85 \%$. 


\section{SIMPULAN}

Berdasarkan uraian pembahasan di atas, maka diperoleh simpulan bahwa:

1. Penerapan metode resitasi pada materi otonomi daerah dalam pelajaran PPKn dimulai dengan memberikan tugas kepada siswa untuk membuat ringkasan dari artikel-artikel yang terdapat pada kliping. Pada pembelajaran selanjutnya setiap kelompok mendapatkan tugas untuk melakukan diskusi. Hal ini dimaksudkan untuk meningkatkan keterlibatan siswa dalam pembelajaran.

2. Metode resitasi dapat meningkatkan hasil belajar materi otonomi daerah dalam pelajaran PPKn. Hal ini berdasar hasil penelitian yang terus meningkat dari siklus pertama hingga terakhir. Pada siklus pertama didapat nilai ratarata sebesar 69. Siswa yang telah mencapai ketuntasan belajar sebanyak 22 siswa atau sebesar 66,7\%. Pada siklus kedua didapat nilai rata-rata sebesar 79,2. Siswa yang telah mencapai ketuntasan belajar sebanyak 29 siswa atau sebesar $87,9 \%$.

Saran yang dapat diberikan dalam penelitian ini adalah sebagai berikut:

1. Untuk Guru

a. Guru hendaknya senantiasa menganjurkan kepada siswa melakukan perhitungan dengan cermat apabila melakukan interaksi perdagangan. Hal ini dimaksudkan untuk meningkatkan kemampuan berfikir kritis.

b. Selalu meningkatkan pengetahuan metodologi pembelajaran.

c. Khususnya guru bidang studi PPKn, untuk dapat menggunakan metode resitasi, dalam kegiatan mengajar materi otonomi daerah.

2. Untuk Siswa

a. Adanya peningkatan kemampuan siswa dalam memahami dan menyelesaikan soal-soal yang berhubungan dengan otonomi daerah.

b. Menumbuhkan sikap gemar PPKn.

3. Untuk Peneliti

Para peneliti di bidang pendidikan dapat melakukan penelitian serupa dengan teknik pembelajaran yang berbeda sehingga didapatkan berbagai alternatif teknik materi otonomi daerah dalam pelajaran PPKn.

\section{DAFTAR PUSTAKA}

Arsyad, Azhar. (2002). Media Pembelajaran. Jakarta: Raja Grafindo Persada.

Blanchard, Alan. 2001. Contectual

Teaching and Learning. B.E.S.T.

Dahar, Ratna Wilis. (2002). Teori-teori Belajar. Jakarta: Erlangga.

Darsono, Max, dkk. 2000. Belajar dan Pembelajaran. Semarang: IKIP Semarang Press.

Depdikbud. 2002. Kamus Besar Bahasa Indonesia edisi 2. Jakarta: Balai Pustaka

Dimyati dan Mujiyono. 2002. Belajar dan Pembelajaran. Jakrata: Rineka Cipta.

Moleong, L. J. 2002. Metodologi Penelitian Kualitatif. Bandung: Remaja Rosdakarya.

Munib, Achmad. 2006. Pengantar Ilmu Pendidikan. Semarang: UPT UNNES Press 
Ni'am, Sholeh, Asrorun. 2006.

Membangun Profesionalitas

Guru:analisis Kronologis atas

Lahirnya UU Guru dan Dosen.

Jakarta: ElSas

Nur, M. 2001. Media Pengajaran dan

Tekhnologi untuk Pembelajaran.

Surabaya: Unesa

Sudjana, 2005. Metode \& Tehnik Pembelajaran Partisipatif.

Bandung . Falah Production

Sukmadinata, Nana Syaodih. 2004.

Metode Penelitian Pendidikan.

Bandung PT. Remaja Rosdakarya.

Suryabrata, Sumadi. 2004. Psikologi

Pendidikan. Jakarta: Raja Grafindo

Persada.

Syah, Muhibin. 2000. Psikologi

Pendidikan dengan Pendekatan

Baru. Bandung: Remaja Rosda Karya.

Wardani, Igak. 2001. Praktik Mengajar. Jakarta: Dirjen Dikti Depdikbud.

Wardani, Igak. 2001. Dasar-dasar Komunikasi dan Keterampilan Dasar Mengajar.

Jakarta : Dirjen Dikti Depdikbud.

Wibawa, Basuki. 2003. Penelitian

Tindakan Kelas. Jakarta.

Depdiknas. 